\title{
Influence of Limited Water Stress on Yield and Fruit Quality of Melon under Soil-Borne Pathogens
}

\author{
Aynur ÖZBAHÇE ${ }^{1 *} \quad$ A. Fuat TARI $\quad$ Seral YÜCEL ${ }^{3} \quad$ Oktay OKUR $^{1} \quad$ Hüseyin PADEM ${ }^{4}$
}

\author{
'Soil, Fertilizer and Water Resources Center Research Institute, Ankara-Turkey \\ ${ }^{2}$ Harran University, Department of Agricultural Irrigation, Urfa-Turkey \\ ${ }^{3}$ Biological Control Research Station, Adana-Turkey \\ ${ }^{4}$ International Burch University, Faculty of Engineering, Department of Genetics and Bioengineering, Bosnia-Herzegovina \\ *Corresponding author e-mail (Sorumlu yazar) : a_ozbahce@hotmail.com \\ Received date (Geliș tarihi ) : 12.02.2014 \\ Accepted date (Kabul tarihi) : 04.03.2014
}

\section{Abstract}

This study was carried out to determine crop response to limited water under biotic stress that was soil-borne pathogens caused of Fusarium oxysporum f.sp. melonis and Macrophomina phaseoli. The experiment was established in a naturally infected field as in a randomized block design with four replications at Cumra in the Konya Plain, Turkey. Irrigation treatments were consisted of four levels: Water amount applied to replenish the water deficit of $0-90 \mathrm{~cm}$ soil depth to field capacity $\left(I_{1}\right)$, water supply reductions of 0.25 and 50 percent were applied for the other treatments. The highest yield $(2.42$ and $3.14 \mathrm{t} \mathrm{da}^{-1}$ ) was obtained from $\mathrm{I}_{1}$ treatment in both years. Other fruit quality parameters were significantly affected by the treatments. The total irrigation water amount and water consumptive use of the same application were 260 and $470 \mathrm{~mm}$ in 2011 , respectively. In the second year, the total irrigation water amount and water consumptive use of the same treatment were 334 and $501 \mathrm{~mm}$, respectively. The higher disease incidence (50.0-54.7\%) was observed in the plants subjected to drought in two-year.

Key Words: Melon, soil-borne pathogens, quality, yield, water stress

\section{INTRODUCTION}

Turkey takes place as the secondary gene centre of melon. The total commercial acreage for melon in Turkey is estimated around 110,000 ha with 1.7 million tons of production. China is by far the main producing country while Turkey follows with $9.4 \%$ of the global production (Anonymous, 2012).

However, some factors such as a reduction of water resources and decrease in agricultural lands, unfavourable conditions as if soil-borne pathogens, salinity and aridity are restricting to take more yield per unit area in agricultural production (Estrella et al., 2003). This fact obligates to improve new growing techniques. Productivity used to be dropping off substantially in melon growing due to these stress conditions in particular in soil. Soil-borne pathogens (Fusarium oxysporum f.sp.melonis'in 0, 1, 1-2 races) are the main limitation on commercial melon yield in the East Mediterranean region (Yücel et al., 1994). In the study region, melon is commonly irrigated by sprinkler method. This case also leads to the development of pathogens.
On the other hand, reduction in rainfall correlatively in water resources create a serious problem especially in Central Anatolia Region of Turkey as if happens in most part of the World. Due to increasing demand for irrigation water surface and underground water sources, the water resources in Konya Basin are progressively depleting. That's why including crops with low water requirement as melon in the crop rotation would enable coping with the water scarcity problem in the region. This is essential for sustainable farming and balanced environment.

Generally, irrigation affects yield and yield components of melon. The most sensitive for soil water deficit are the fruit setting and flowering stages (Faberio et al., 2002). Hartz (1997), Sensoy et al., (2007) and Dogan et al., (2008) reported that more irrigation increased yield but reduced soluble solid content compared to dry land conditions.

Yield and quality of melon are decreased due to water scarcity and soil-borne pathogens in the study 
region. This research was carried out to determine the influence of limited water on yield, quality and water use efficiency of melons under soil-borne pathogens stress. Additionaly, the effect of water stress on the development of soil-borne pathogens was also investigated.

\section{MATERIAL AND METHODS}

\section{Experimental site and crop management}

The experiments were conducted in a field naturally infected with Fusarium oxysporum f.sp.melonis and Macrophomina phaseoli during the growing season of 2011 and 2012 from May to August at the Cumra region in the Konya Plain. The field experiments were established in randomized blocks with four replications.

Total precipitation amounts during the vegetation period from May to August were recorded at 65 and $3 \mathrm{~mm}$ in 2011 and 2012, respectively. The average temperature was $20.6{ }^{\circ} \mathrm{C}$ and $21.4^{\circ} \mathrm{C}$ in the study years, respectively. In 2011 , the soil analysed was a clay loam that is common in soils of the region. The soil texture contains $32 \%$ clay, $19 \%$ silt and $48 \%$ sand and soil $\mathrm{pH}$ is 8.4 . In the second year, soil texture was $22 \%$ clay, $27 \%$ silt and $51 \%$ sand and soil $\mathrm{pH}$ is 8.0 . The soil has, thus, a sandy-clayeyloamy consistency.

Melon seedlings (Cucumis melo cv. Edalı F1) were supplied by the YASA Seedling Company (Antalya, Turkey). They were planted at a $2.0 \mathrm{~m}$ interrow width, and given $0.75 \mathrm{~m}$ spacing on May 20 , 2011, and May 18, 2012, respectively. The dimensions of the plot were $9 \mathrm{~m} \times 8 \mathrm{~m}\left(72 \mathrm{~m}^{2}\right)$. A total of $150 \mathrm{~kg} \mathrm{Nha}^{-1}, 100 \mathrm{kgP}_{2} \mathrm{O}_{5} \mathrm{ha}^{-1}$, and $100 \mathrm{~kg}$ $\mathrm{K}_{2} \mathrm{O} \mathrm{ha}{ }^{-1}$ fertilizers were applied during the growing season. Half of nitrogen and the whole of phosphorus and potassium were applied to the soil before the seedlings were planted. The remaining nitrogen fertilizer was applied via drip irrigation system fertigation during the growing period. Harvests occurred on Aug. 8, 2011 and Aug. 9, 2012, respectively.

\section{Irrigation applications}

The irrigation method was drip irrigation. A dripper lateral was use for each melon row. Irrigation times were determined according to the growth stages of the plants (early vegetative, late vegetative, flowering, fruit setting and ripening). The amount of irrigation water required to fill the soil depth of 0-90 cm to field capacity was applied to the treatment $\left(l_{1}\right)$. In addition, 75 and $50 \%$ of the treatment $I_{1}$ was applied $I_{2}$ and $I_{3}$, respectively. The irrigation was not applied for the treatment $I_{0}$. The percentage of wetting area was determined as far as the growth period of plant. The wetted area was used to calculate the amount of irrigation water applied, thus it considered as $40 \%$ and $30 \%$ for flowering and the later periods, respectively.

Irrigation duration was determined by dividing the total irrigation amount by the number and total discharge of the emitters in the plots. These amounts were applied trough water flow meter in the plot. Soil moisture content was determined by gravimetric method. The moisture available in the soil layer of 0$90 \mathrm{~cm}$ of treatment with most favourable moisture conditions $\left(I_{1}\right)$ was used in the calculation procedure of the irrigation water amount.

Evapotranspiration (ET) of the treatments was determined using the equation 1 (James, 1988).

$$
E T=I+P+D P \pm \text { Roff } \pm \Delta S
$$

Where, ET is water consumptive $(\mathrm{mm}), \quad I$ is irrigation water $(\mathrm{mm}), P$ is the rainfall $(\mathrm{mm}), \mathrm{Dp}$ is the deep percolation $(\mathrm{mm})$, Roff is the runoff $(\mathrm{mm})$ and $\Delta S$ is the change of moisture content in the root depth (mm).

\section{Statistical Evaluation}

Experimental results related to fruit yield and crop quality were subjected to a variance analysis according to a procedure described by Yurtsever (1984) and the Duncan mean separation test procedure. The mean percent disease values from all plants, per treatment, were calculated after harvest.

Fruit yield and quality, irrigation water use efficiency (IWUE) and water use efficiency (WUE)

Fruit yield was calculated from matured fruit at harvest time as $t d^{-1}{ }^{-1}$. Some characteristics of the fruit were investigated after harvest. Single plant yield (SPY-kg plant ${ }^{-1}$ ), number of fruit per plant (NFPnumber plant ${ }^{-1}$ ), mean fruit weight (MFW-g), fruit diameter (FD-mm, with a compass at the middle of fruit), height of the core $(\mathrm{CH}-\mathrm{cm})$, diameter of the core (CD-cm), fruit coat thickness (FCT-cm) and fruit flesh thickness (FFT-cm) were noted for approximately eight fruits per plot, randomly collected as subsamples for quality assessment. The fruits were then homogenized in a blender, and portions of the homogenate analyzed to evaluate the $\mathrm{pH}$ (determined by the $\mathrm{pH}$-meter), total soluble 
solids (TSS) (\%, determined by the refract meter), sucrose, and total and inverted sugar content (\%). They were measured by the titration method (Ekinci and Dursun, 2006).

Irrigation water use efficiency (IWUE, $\mathrm{kg} \mathrm{m}^{-3}$ ) and water use efficiency (WUE, $\mathrm{kg} \mathrm{m}^{-3}$ ) were calculated from the fruit yield $\left(\mathrm{kg} \mathrm{ha}^{-1}\right)$ and amount of applied water $\left(\mathrm{l}, \mathrm{m}^{3}\right)$ and water use consumptive $\left(E T, \mathrm{~m}^{-3}\right.$ ) (Howell, 1990).

\section{RESULTS}

Fruit yield and some quality characteristics of melon

The yield data of the treatments are given in Table 1. There were significant differences among the treatments for both years $(p<0.01)$. The maximum yield was obtained from $I_{1}$ applications in

Table 1. Fruit yield obtained from treatments

\begin{tabular}{|l|c|c|c|}
\hline \multirow{2}{*}{ Treatments } & \multicolumn{2}{|c|}{ Yield $\left(\mathrm{t} \mathrm{da}^{-1}\right)^{*}$} & \multirow{2}{*}{ Mean } \\
\cline { 2 - 4 } & 2011 & 2012 & \\
\hline $\mathrm{I}_{0}$ & $0.67 \mathrm{~cd}$ & $1.22 \mathrm{~d}$ & 0.94 \\
\hline $\mathrm{I}_{1}$ & $2.42 \mathrm{a}$ & $3.14 \mathrm{a}$ & 2.78 \\
\hline $\mathrm{I}_{2}$ & $2.23 \mathrm{ab}$ & $2.41 \mathrm{~b}$ & 2.32 \\
\hline $\mathrm{I}_{3}$ & $1.39 \mathrm{c}$ & $2.14 \mathrm{c}$ & 1.76 \\
\hline
\end{tabular}

*values followed by the same letter do not differ significantly at $\mathrm{p}<0.01$ by Duncan test both years, reaching $2.42 \mathrm{t} \mathrm{da}^{-1}$ in 2011 and 3,14 t $\mathrm{da}^{-1}$ in 2012. However, there were no significant differences between treatment $I_{1}$ and $I_{2}$ in 2011 . The lowest yield was obtained from the treatment $I_{0}$ (0.67-1.22 $\mathrm{t} \mathrm{da}^{-1}$ ) for each year (Table 1).

The effects of the treatments on some quality characteristics of melons are presented in Table 2 and 3. During the 2-years, irrigation did not have any effect on $\mathrm{CH}, \mathrm{CD}, \mathrm{FCT}$ and FFT. However, SPY, NFP, MFW and FD were significantly affected by treatments $(p<0.05)$. The highest SPY was obtained from the $I_{1}\left(3.6-5.4 \mathrm{~kg}\right.$ plant $\left.^{-1}\right)$ treatment, while the highest NFP was recorded as 2.1-2.7 number plant $^{-1}$ and obtained from the $I_{1}$ application in both years. The highest mean fruit weight was determined as 2.8-3.0 kg recorded for $\left(I_{1}\right)$ treatment, respectively. However, there were no significant differences among $I_{1}$ and $I_{2}(2.7 \mathrm{~kg}), I_{3}$ $(2.7 \mathrm{~kg})$, in the first year. The highest FD (51.1-51.8 $\mathrm{cm}$ ) was obtained from I, treatments, in both years. Fruit diameter was also reduced significantly by water stress.

Irrigation treatments did not significantly affect $\mathrm{pH}$ and sugar content, but TSS was affected by treatments in both years. The highest TSS content $(10 \%)$ was obtained from the $I_{0}-I_{3}$ applications in the first year. In the second year, I application had the highest TSS content as \% 9 (Table 4).

Table 2. The effect of treatments on some quality characteristics

\begin{tabular}{|l|c|c|c|c|c|c|c|c|}
\hline \multirow{2}{*}{ Treatments } & \multicolumn{2}{|c|}{ SPY $\left(\mathrm{kg}^{2} \text { plant }^{-1}\right)^{*}$} & \multicolumn{2}{c|}{ NFP $\left(\text { number } \text { plant }^{-1}\right)^{*}$} & \multicolumn{2}{c|}{ MFW $(\mathrm{kg})^{*}$} & \multicolumn{2}{c|}{$\mathrm{CH}(\mathrm{cm})^{\text {ns }}$} \\
\cline { 2 - 10 } & 2011 & 2012 & 2011 & 2012 & 2011 & 2012 & 2011 & 2012 \\
\hline $\mathrm{I}_{0}$ & $0.9 \mathrm{c}$ & $1.8 \mathrm{c}$ & $1.0 \mathrm{c}$ & $1.2 \mathrm{c}$ & $1.5 \mathrm{~b}$ & $1.6 \mathrm{c}$ & 15.5 & 14.0 \\
\hline $\mathrm{I}_{1}$ & $3.6 \mathrm{a}$ & $5.4 \mathrm{a}$ & $2.1 \mathrm{a}$ & $2.7 \mathrm{a}$ & $2.8 \mathrm{a}$ & $3.0 \mathrm{a}$ & 13.1 & 12.8 \\
\hline $\mathrm{I}_{2}$ & $3.1 \mathrm{ab}$ & $3.6 \mathrm{~b}$ & $1.6 \mathrm{~b}$ & $2.0 \mathrm{~b}$ & $2.7 \mathrm{a}$ & $2.0 \mathrm{~b}$ & 13.2 & 12.3 \\
\hline $\mathrm{I}_{3}$ & $2.2 \mathrm{~b}$ & $3.5 \mathrm{~b}$ & $1.8 \mathrm{~b}$ & $1.7 \mathrm{~b}$ & $2.7 \mathrm{a}$ & $2.1 \mathrm{~b}$ & 13.8 & 14.1 \\
\hline
\end{tabular}

* values followed by the same letter do not differ significantly at $\mathrm{p}<0.05$ by Duncan test, ns: non significant SPY-Single plant yield, NFP-number of fruit per plant, MFW-mean fruit weight, $\mathrm{CH}$-height of the core

Table 3. The effect of treatments on other quality characteristics

\begin{tabular}{|l|c|c|c|c|c|c|c|c|}
\hline \multirow{2}{*}{ Treatments } & \multicolumn{2}{|c|}{$\mathrm{FD}(\mathrm{cm})^{*}$} & \multicolumn{2}{c|}{$\mathrm{CD}(\mathrm{cm})^{\mathrm{ns}}$} & \multicolumn{2}{c|}{$\mathrm{FCT}(\mathrm{cm})^{\mathrm{ns}}$} & \multicolumn{2}{c|}{$\mathrm{FFT}(\mathrm{cm})^{\text {ns }}$} \\
\cline { 2 - 11 } & 2011 & 2012 & 2011 & 2012 & 2011 & 2012 & 2011 & 2012 \\
\hline $\mathrm{I}_{0}$ & $34.9 \mathrm{c}$ & $42.8 \mathrm{~b}$ & 3.6 & 4.5 & 1.0 & 0.8 & 3.0 & 3.0 \\
\hline $\mathrm{I}_{1}$ & $51.1 \mathrm{a}$ & $51.8 \mathrm{a}$ & 5.6 & 6.5 & 1.5 & 1.4 & 4.3 & 5.3 \\
\hline $\mathrm{I}_{2}$ & $48.8 \mathrm{a}$ & $51.1 \mathrm{a}$ & 6.0 & 6.3 & 1.1 & 1.1 & 4.0 & 5.2 \\
\hline $\mathrm{I}_{3}$ & $44.1 \mathrm{ab}$ & $47.2 \mathrm{~b}$ & 4.6 & 5.3 & 1.2 & 0.8 & 3.5 & 4.1 \\
\hline
\end{tabular}

* values followed by the same letter do not differ significantly at $p<0.05$ by Duncan test, ns: non significant FD-fruit diameter, CD-diameter of the core, FCT-fruit coat thickness, FFT-fruit flesh thickness 
Influence of Limited Water Stress on Yield and Fruit Quality of Melon under Soil-Borne Pathogens

Table 4. $\mathrm{pH}$, total soluble solids (TSS) and sugar content obtained from treatments

\begin{tabular}{|c|c|c|c|c|c|c|c|c|c|c|}
\hline \multirow{3}{*}{ Treatments } & \multirow{2}{*}{\multicolumn{2}{|c|}{$\mathrm{pH}^{\mathrm{ns}}$}} & \multirow{2}{*}{\multicolumn{2}{|c|}{$\operatorname{TSS}(\%)^{*}$}} & \multicolumn{6}{|c|}{ Sugar $(\%)^{\text {ns }}$} \\
\hline & & & & & \multicolumn{2}{|c|}{ Total } & \multicolumn{2}{|c|}{ Invert } & \multicolumn{2}{|c|}{ Sucrose } \\
\hline & 2011 & 2012 & 2011 & 2012 & 2011 & 2012 & 2011 & 2012 & 2011 & 2012 \\
\hline $\mathrm{I}_{0}$ & 3.0 & 3.0 & 10.0a & $9.0 a$ & 7.1 & 6.9 & 3.7 & 3.8 & 3.2 & 2.9 \\
\hline$I_{1}$ & 4.3 & 5.3 & $6.9 c$ & $6.3 c$ & 6.8 & 6.2 & 3.9 & 3.4 & 2.7 & 2.6 \\
\hline $\mathrm{I}_{2}$ & 4.0 & 5.2 & $9.1 \mathrm{~b}$ & $6.3 c$ & 7.4 & 7.0 & 3.6 & 3.8 & 3.6 & 3.2 \\
\hline$I_{3}$ & 3.5 & 4.1 & 10.0a & $7.3 \mathrm{~b}$ & 7.5 & 7.2 & 3.7 & 3.6 & 3.2 & 3.4 \\
\hline
\end{tabular}

* values followed by the same letter do not differ significantly at $\mathrm{p}<0.05$ by Duncan test, ns: non significant

\section{The disease incidence}

During the 2-year, environmental factors were favourable for the development of infection caused by Fusarium oxysporum f.sp.melonis and Macrophomina phaseoli, which resulted in 50.00$54.69 \%$, respectively (Table 5 ).

The disease incidence was significantly affected by irrigation treatments. The disease incidence decreased with increasing irrigation rates. The maximum irrigation water treatment $\left(l_{1}\right)$ observed lower disease incidence $(28.12 \%)$ than other irrigation levels. Moreover, melon yield increased proportionally to a decrease in the disease incidence (Figure 1).

\section{Amount of applied irrigation water (IW), water consumptive use (ET), and irrigations efficiencies IWWE and WUE}

The amount of irrigation water, evapotranspiration and efficiencies are given Table 6. The total amount of irrigation water and water consumptive use of $I_{1}$ were determined as 260 and $470 \mathrm{~mm}$ in 2011 , respectively. In 2012, the total applied irrigation water and water consumptive use of the same treatment were $334 \mathrm{~mm}$ and $501 \mathrm{~mm}$, respectively. Total precipitation amounts during the vegetation period from planting to harvest were recorded as $65 \mathrm{~mm}$ in 2011 and $3 \mathrm{~mm}$ in 2012. As far as the subject water application, a fix total water of $26 \mathrm{~mm}$ and $62 \mathrm{~mm}$ was applied in the first and the second experimental years, respectively.

Table 5. Disease incidence of treatments

\begin{tabular}{|l|c|c|c|c|c|c|}
\hline \multirow{2}{*}{ Treatments } & \multicolumn{2}{|c|}{ Disease plant } & \multicolumn{2}{c|}{ Healthy plant } & \multicolumn{2}{c|}{ Disease incidence (\%) } \\
\cline { 2 - 7 } & 2011 & 2012 & 2011 & 2012 & 2011 & 2012 \\
\hline$I_{0}$ & 24.0 & 26.25 & 24.0 & 21.75 & 50.00 & 54.69 \\
\hline$I_{1}$ & 13.5 & 12.5 & 34.5 & 35.50 & 28.12 & 26.04 \\
\hline$I_{2}$ & 15.5 & 15.75 & 32.5 & 32.25 & 32.29 & 32.81 \\
\hline$I_{3}$ & 22.0 & 19.0 & 26.0 & 29.0 & 45.83 & 39.58 \\
\hline
\end{tabular}

(10

Figure 1. Relations between yield and disease incidence 
IWUE values ranged from $9.3\left(I_{1}\right)$ to $11.4\left(I_{2}\right)$ and from $9.4\left(I_{1}\right)$ to $12.8\left(I_{3}\right) \mathrm{kg} \mathrm{m}^{-3}$ for the first and second experimental years, respectively. Water use efficiencies (WUE) ranged from $2.7\left(\mathrm{I}_{0}\right)$ to $5.3\left(\mathrm{I}_{2}\right) \mathrm{kg}$ $\mathrm{m}^{-3}$ and $5.6\left(\mathrm{I}_{2}\right)$ to $6.2\left(\mathrm{I}_{1}\right) \mathrm{kg} \mathrm{m}^{-3}$ depending on the treatments and experimental years. The maximum WUE value was $5.3-6.2 \mathrm{~kg} \mathrm{~m}^{-3}$ water applied in the treatments $\mathrm{I}_{2}-\mathrm{I}_{1}$ according to years, respectively (Table 6).

As a result, INUEs differ considerably among the treatments and generally tends to increase with a decline in irrigation (Figure 2). As mentioned above, this might be attributed to differences in the amount of irrigation water or fruit yield obtained due to climatological and soil conditions. As the results in this study, irrigation scheduling can improve water use efficiency along with efficient irrigation scheduling management.

\section{DISCUSSION}

The fruit yield was affected by irrigation treatments. In 2011 , yield obtained from treatment containing application of $75 \%$ of full irrigation water did not differ from the yield recorded for most irrigated $I_{1}$ treatment. These results suggest that the crop is not very sensitive to moderate water deficits up to $25 \%$. While severe water stress due to irrigation water reduction by $50 \%$ or nonirrigation lead to yield decreases up to $42 \%$ and $72 \%$, respectively. These results were similar to data of Alizadeh et al., (1999), Lei et al., (2003) and Yıldırım et al., (2009). Thus, the treatment of limited irrigation water may improve the yield compared to full irrigation application.

In the second year, the yield was decreased with reducing irrigation rates. An irrigation level

Table 6. Irrigation water amount (I), seasonal evapotranspiration (ET), irrigation water use efficiency (IWUE) and water use efficiency (WUE) according to the experimental years

\begin{tabular}{|c|c|c|c|c|c|c|c|c|}
\hline \multirow{2}{*}{$\begin{array}{c}\text { Treatments } \\
(\mathrm{IL} \times \mathrm{F})\end{array}$} & \multicolumn{2}{|c|}{2011} & \multicolumn{2}{c|}{2011} & \multicolumn{2}{c|}{2012} & \multicolumn{2}{c|}{2012} \\
\cline { 2 - 8 } & $\begin{array}{c}\mathrm{I} \\
(\mathrm{mm})\end{array}$ & $\begin{array}{c}\mathrm{ET} \\
(\mathrm{mm}\end{array}$ & $\begin{array}{c}\text { IWUE } \\
\left(\mathrm{kgm}^{-3}\right)\end{array}$ & $\begin{array}{c}\text { WUE } \\
\left(\mathrm{kgm}^{-3}\right)\end{array}$ & $\begin{array}{c}\mathrm{I} \\
(\mathrm{mm})\end{array}$ & $\begin{array}{c}\mathrm{ET} \\
(\mathrm{mm})\end{array}$ & $\begin{array}{c}\text { IWUE } \\
\left(\mathrm{kgm}^{-3}\right)\end{array}$ & $\begin{array}{c}\text { WUE } \\
\left(\mathrm{kgm}^{-3}\right)\end{array}$ \\
\hline $\mathrm{I}_{0}$ & - & 240 & - & 2.7 & - & 208 & - & 5.8 \\
\hline $\mathrm{I}_{1}$ & 260 & 470 & 9.3 & 5.1 & 334 & 501 & 9.4 & 6.2 \\
\hline $\mathrm{I}_{2}$ & 195 & 413 & 11.4 & 5.3 & 251 & 430 & 9.6 & 5.6 \\
\hline $\mathrm{I}_{3}$ & 130 & 362 & 10.6 & 3.8 & 167 & 362 & 12.8 & 5.9 \\
\hline
\end{tabular}

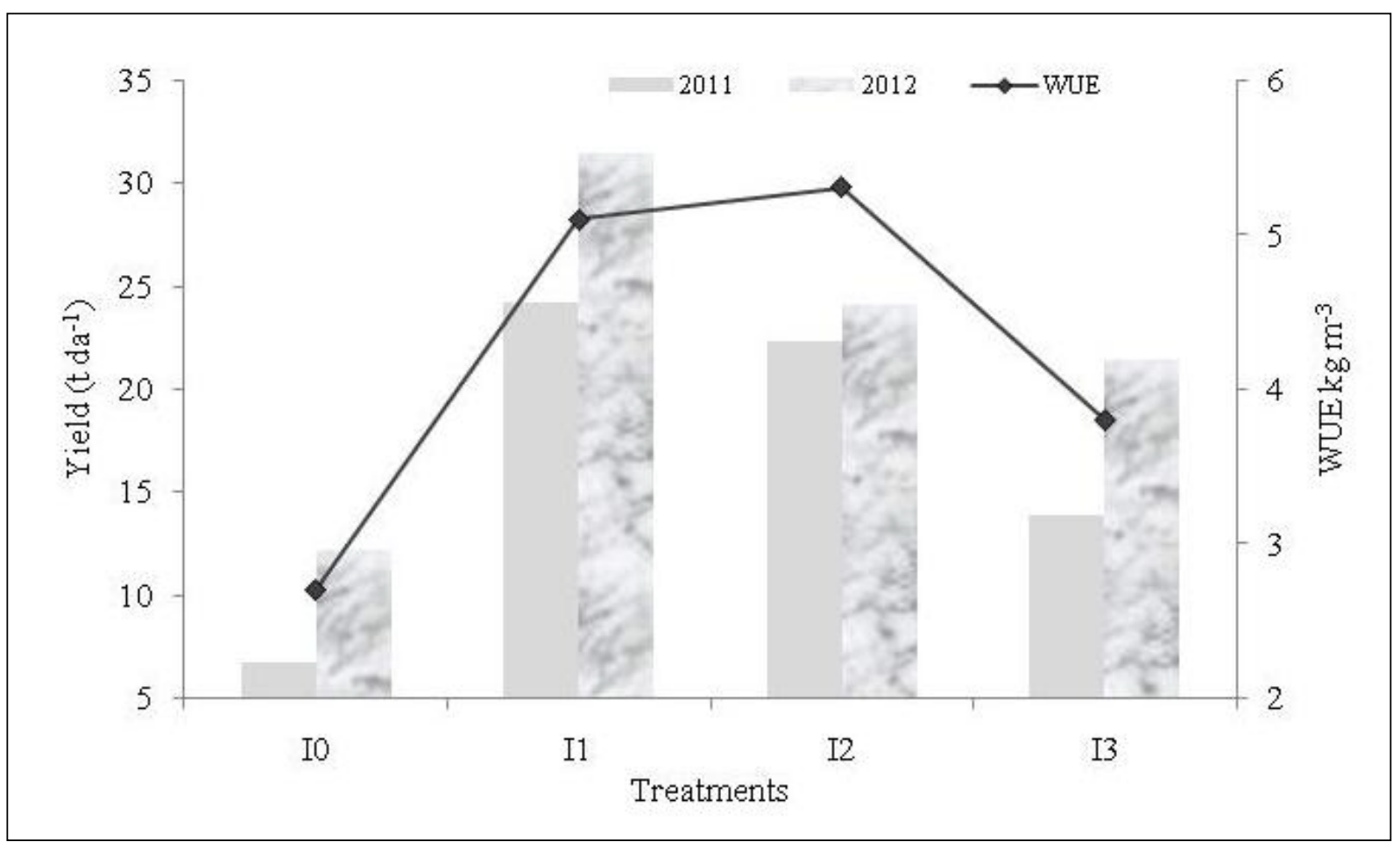

Figure 2. Melon yield and water use efficiency (average values for 2-year) 
reduce of $25,50 \%$ of $I_{1}$ and non-irrigation decreased melon fruit yield by 23, 31 and $61 \%$, respectively. Kirnak et al., (2005), Sensoy et al., (2007) and Cabello et al., (2009) found that melon crop showed a negative response to irrigation deficit. Besides, Dogan et al., (2008) determined that under semiarid climatic conditions, any reduction in irrigation amount from about 83-92\% of class A pan evaporation values would result in reduced melon yield. Yıldırım et al., (2009) investigated melon plants which were drip-irrigated at $50 \%, 75 \%$ and $100 \%$ of full irrigation water. Yield in $I_{75}$ and $I_{100}$ was found similar.

In this study, some quality characteristics (SPY, NFP, MFW, FD and TSS) increased with the application of no water stress, in both experiment years. Application of lower irrigation increased total soluble solids of fruit. Full irrigation water treatment resulted in bigger and heavier fruits. Similar results were found by Sensoy et al., (2007), Dogan et al., (2008) and Cabello et al., (2009). Faberiro et al., (2002) stated that fruit yield and its components were highly influenced by the total volume of irrigation water. The treatments with a deficit decreased both yield and quality. Yıldırım et al., (2009) determined that TSS content increased with decreasing irrigation level. Al-Mefleh et al., (2012) stated that fruit diameter and weight was increased with increasing irrigation water amounts. But, the authors found out that fruit sugar content was decreased with irrigation levels.

The pathogens generally increased with decreasing soil moisture content. At low soil wetness, development of Fusarium wilt was increased (Ben-Yephet and Frank, 1985; Martyn and Gordon, 1998).

Treatments with lower amounts of water have generally higher IWUE values. On the other hand, WUEs usually increases with increasing in irrigation (Howell, 2006). Similar results have been reported by Kirnak et al., (2005), Sensoy et el., (2007) and Cabello et al., (2009) in melon.

\section{CONCLUSIONS}

According to results obtained from the 2-year study, melon yield and some quality characteristics (single plant yield, number of fruit per plant, mean fruit weight, fruit diameter and total soluble solids) are strongly affected by irrigation levels. These parameters were increased at the optimum irrigation water amount. In both years, the maximum yield was obtained from $I_{1}$ applications, reaching $2.42 \mathrm{t} \mathrm{da}^{-1}$ in 2011 and $3.14 \mathrm{t} \mathrm{da}^{-1}$ in 2012. The total water consumptive use of $I_{1}$ application was 470 and 501 mm, respectively.

Besides, the disease incidence changed depended on soil moisture content. The disease incidence increased with decreasing of soil moisture content. In plants subjected to drought showed the highest disease incidence. The highest disease incidence (50.0-54.7\%) was observed in the plants subjected to drought in two-year.

These results suggest that moderate deficit irrigation does not decrease IWUE, while WUE usually increases with increasing in irrigation. On the contrary, high IWUE is obtained from severe water stress.

\section{Acknowledgements}

The study, No. TAGEM-BB100201-F-021, was supported by the General Directorate of Agricultural Research and Policies, Turkey.

\section{REFERENCES}

Alizadeh K A, Baghani J M, Haghnia G M (1999). Effect of deficit irrigation by drip and furrow systems on yield and quality of melon at Mashad, Iran. In: 17th 212 ICID International Congress on Irrigation and Drainage, 1:263-269.

Al-Mefleh N K, Samarah N, Zaitoun S, Al-Majeed Al-Ghzawi A (2012). Effect of irrigation levels on fruit characteristics, total fruit yield and water use efficiency of melon under drip irrigation system. Journal of Food, Agriculture \& Environment, 10: $540-545$.

Anonymous (2012). Agricultural structure and production. Goverment Statistic Institute of Prime Minister Publication. Available from: http://www.tuik.gov.tr (in Turkish).

Ben-Yephet Y, Frank Z R (1 985). Effect of soil structure on penetration by metham-sodium and of temperature on concentrations required to kill soil-borne pathogens. Phytopatlogy, 75: 403-406.

Cabello M J, Castellanos M T, Romojaro F, Martinez-Madrid C, Ribas F (2009). Yield and quality of melon grown under different irrigation and nitrogen rates. Agricultural Water Management, 96: 866-874.

Dogan E, Kirnak H, Berekatoglu K, Bilgel L, Surucu A (2008). Water stress imposed on muskmelon (Cucumis melo L.) with subsurface and surface drip irrigation systems under semi-arid climatic conditions. Irrigation Science, 26: 131-138.

Ekinci M, Dursun A (2006). The effects of different mulch materials on plant growth some quality properties and yield in melon. VI. Vegetable Agriculture Symposium.pp. 320-324, $19-$ 22 September, K.Maraș, Turkey, (in Turkish).

Estrella F S, Vargas-Garcia M C, Lopez M J, Moreno J (2003). Survival of Fusarium oxysporum f.sp. melonis on plant waste. Crop Production. 23 (2): 127-133. 
Fabeiro C, Martin De Santa Olalla F, De Juan J A (2002). Production of muskmelon (Cucumis melo L.) under controlled deficit irrigation in a semi-arid climate. Agricultural Water Management, 54: 93-105.

Hartz T K (1997). Effects of drip irrigation scheduling on muskmelon yield and quality. Scientia Horticulturae, 69: 117122

Howell T A (2006). Challenges in increasing water use efficiency in irrigated agriculture. In: The Proceedings of International Symposium on Water and Land Management For Sustainable Irrigated Agriculture, April 4-8, Adana-Turkey.

Howell T A, Cuenca R H, Solomon K H (1990). Crop yield response. Management of Farm Irrigation Systems (Ed. Hoffman et al.). ASAE, pp:311- 312.

James L G (1988). Principles of farm irrigation system design. John Wiley and Sons. Inc, New York, p.543.

Kirnak H, Higgs D, Kaya C, Tas I (2005). Effects 246 of irrigation and nitrogen rates on growth, yield, and quality of muskmelon in semiarid regions. Journal of Plant Nutrition, 28: 621-638

Lei T W, Xiao J, Wang J P, Liu Z Z, Li G Y, Zhang J G, Mao $J M$ (2003). Experimental investigation into effects of drip irrigation with saline ground water on water use efficiency and quality of honeydew melons in Hetao region Inner Mongolia. Transactions of the Chinese Soc. Agric. Eng., 19: 80-84.
Martyn R D, Gordon T R (1998). Compendium of cucurbit diseases. APS Press. 87: 14-15.

Sensoy S, Ertek A, Gedik I, Kucukyumuk C (2007). Irrigation frequency and amount affect yield and quality of field-grown melon (Cucumis melo L.). Agricultural Water Management, 88: 269-274.

Yıldırım O, Halloran N, Çavușoğlu Ș, Șengül N (2009). Effects of different irrigation programs on the growth, yield, and fruit quality of drip-irrigated melon. Turkish Journal of Agriculture and Forestry, 33:243-255.

Yücel S, Pala H, Sarı N, Abak K (1994). Determination of Fusarium oxysporum f.sp. melonis races in the East Mediterranean Region of Turkey and response of some melon genotypes to the disease. 9th Congress of the Mediterranean Phytopathological Union, pp:87-89, September 18-24, Kușadası-Aydın, Türkiye.

Yurtsever N(1984). Experimental statistics methods. Republic of Turkey, Ministry of Agriculture the Former General Directorate of Rural Service, Soil-Fertilizer Research Institute. Publication No.121, Techniques Publication No.56, Ankara, Turkey (in Turkish). 